Article

\title{
Sortase A-Inhibitory Metabolites from a Marine-Derived Fungus Aspergillus sp.
}

\author{
Sung Chul Park ${ }^{1}$, Beomkoo Chung ${ }^{2}$, Jayho Lee ${ }^{2}$, Eunji Cho ${ }^{2}$, Ji-Yeon Hwang ${ }^{1}$, \\ Dong-Chan $\mathrm{Oh}^{1}{ }^{1}$, Jongheon Shin ${ }^{1, *(1)}$ and Ki-Bong $\mathrm{Oh}^{2, *}$ \\ 1 Natural Products Research Institute, College of Pharmacy, Seoul National University, Seoul 08826, Korea; \\ sungchulpark@snu.ac.kr (S.C.P.); yahyah7@snu.ac.kr (J.-Y.H.); dongchanoh@snu.ac.kr (D.-C.O.) \\ 2 Department of Agricultural Biotechnology, College of Agriculture and Life Sciences, Seoul National \\ University, Seoul 08826, Korea; beomkoo01@snu.ac.kr (B.C.); jayho@snu.ac.kr (J.L.); \\ eunji525@snu.ac.kr (E.C.) \\ * Correspondence: shinj@snu.ac.kr (J.S.); ohkibong@snu.ac.kr (K.-B.O.); \\ Tel.: +82-2-880-2484 (J.S.); +82-2-880-4646 (K.-B.O.)
}

Received: 13 June 2020; Accepted: 9 July 2020; Published: 13 July 2020

\begin{abstract}
Seven alkaloidal compounds (2-8) and one polyketide (1) were isolated from a semisolid rice culture of the marine-derived fungus Aspergillus sp. F452. Structures of the isolated compounds were elucidated based on spectroscopic data and comparisons with previously reported data. The alkaloidal compounds (2-8) displayed weak to moderate inhibitory activities against Staphylococcus aureus-derived sortase A (SrtA) without affecting cell viability. Aspermytin A (1) strongly inhibited SrtA activity, with an $\mathrm{IC}_{50}$ value of $146.0 \mu \mathrm{M}$, and significantly reduced bacterial adherence to fibronectin-coated surfaces. The present results indicate that the underlying mechanism of action of compound $\mathbf{1}$ is associated with the inhibition of SrtA-mediated S. aureus adhesion to fibronectin, thus potentially serving as an SrtA inhibitor.
\end{abstract}

Keywords: marine-derived fungus; Aspergillus sp.; metabolites; sortase A; fibronectin

\section{Introduction}

Antibiotic-resistant bacteria are the most prominent limitation in conventional antimicrobial treatment [1]. Microorganisms can acquire antibiotic resistance when their survival is at risk. Whereas antibiotics have a long-standing history of success in treatment of bacterial infections, recent increasing antimicrobial resistance has stimulated the search for anti-virulence drugs as an alternative to conventional antibiotics, despite their high importance, for counteracting bacterial pathogens [2,3].

The pathogenesis of bacterial infections is initiated with bacterial adhesion to host tissue surfaces mediated via specific interactions between host ligands and bacterial surface proteins [4]. In particular, in Gram-positive bacteria including Staphylococcus aureus, this fundamental stage of infection proceeds through sortase-mediated anchoring of surface proteins in host cells to the bacterial cell wall envelope [5]. In S. aureus, sortase A (SrtA) cleaves surface proteins between threonine and glycine residues in LPXTG sorting signals at their C-termini and is subsequently incorporated into the bacterial cell wall envelope via a transpeptidation reaction [6,7]. Numerous knockout studies have revealed that SrtA plays a critical role in the pathogenesis of Gram-positive bacterial infections by modulating bacterial adhesion to host tissues [8-10]. SrtA decorates the surfaces of Gram-positive bacteria with a diverse array of proteins that enable each microbe to effectively interact with its environment and is not required for bacterial growth or viability [2,3]. It is thus considered a promising target for the development of anti-virulence drugs that aim to interfere with important virulence mechanisms, such as adhesion to host tissues. 
The secondary metabolites of marine fungi, including polyketides, alkaloids, terpenes, lactones, and peptides, are a rich source of bioactive natural products [11]. Many bioactive compounds with varying degrees of action, such as antibiotic, antiviral, antimicrobial, and anticancer properties, have been isolated from marine fungal sources. Recent investigations of marine fungal metabolites looking for bioactive compounds indicate their potential as a source of new medicines [12,13]. Previously, we reported several novel natural products isolated from marine-derived fungi; polyaromatic metabolites from Penicillium sp. exhibited moderate cytotoxicity and significant inhibitory activity against $S$. aureus SrtA [14], asperphenins from Aspergillus sp. induced significant cytotoxicity in diverse cancer cells [15], and peptides from A. allahabadii and A. ochraceopetaliformis displayed SrtA inhibitory activity [16].

In further study, chemical investigation of Aspergillus sp. F452 was performed [15], whose crude extract inhibited S. aureus-derived SrtA $(63 \%$ inhibition at $100 \mu \mathrm{g} / \mathrm{mL})$. Bioassay-guided separation of the extract yielded seven alkaloidal (2-8) and one polyketide (1) compound, whose structures were analyzed through combined spectroscopic methods. This study describes the structures and biological activities of these compounds. Among them, compound 1 (aspermytin A) significantly inhibited $S$. aureus-derived SrtA. The in vivo bioactivity and underlying mechanism of action were also found to be associated with the inhibition of SrtA-mediated S. aureus adhesion to the eukaryotic cell matrix protein fibronectin.

\section{Results and Discussion}

\subsection{Isolation and Structure Elucidation of Compounds 1-8}

The fungal strain F452 [15] was cultured in semisolid rice medium and extracted with $\mathrm{MeOH}$ and $\mathrm{CH}_{2} \mathrm{Cl}_{2}$. Following solvent evaporation, the combined extract was separated by solvent partitioning followed by reversed-phase $C_{18}$ vacuum flash chromatography and semi-preparative high performance liquid chromatography (HPLC) to yield eight compounds. Compounds 1-8 were identified as aspermytin A (1) [17], versicomide A (2) [18], versicoloid A (3) [19], isochaetominines A-C (4-6) [20,21], 14-epi-isochaetominine C (7) [21], and fumiquinazoline K (8) [22], respectively, via combined spectroscopic analyses, including high-resolution fast atom bombardment mass spectroscopy, ${ }^{1} \mathrm{H}$ - and ${ }^{13} \mathrm{C}$-nuclear magnetic resonance (NMR), 2-D NMR, and UV spectroscopy (Figure 1). The spectroscopic data for these compounds were in good agreement with those in the literature.<smiles>C[C@H]1CC[C@H]2C=C[C@@H](O)[C@](C)(C(=O)CCO)[C@@H]2C1</smiles>

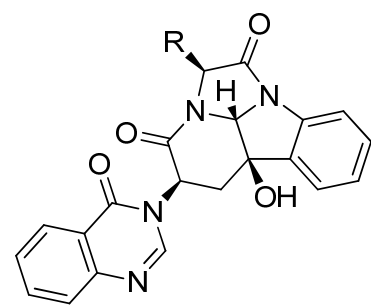

$4 \mathrm{R}=\mathrm{CH}_{3}$

$5 \mathrm{R}=\mathrm{CH}_{2} \mathrm{CH}_{3}$

$6 \mathrm{R}=\mathrm{CH}\left(\mathrm{CH}_{3}\right)_{2}$<smiles>CC[C@H](C)[C@H]1NC(=O)[C@@H](C(C)C)n2c1nc1ccc(OC)cc1c2=O</smiles>

2

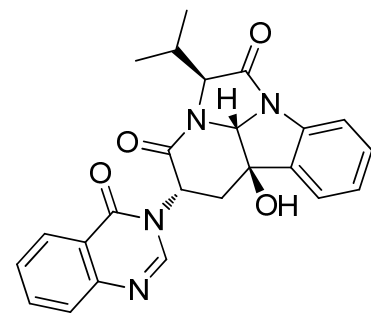

7<smiles>CCC(C)[C@H]1NC(=O)[C@@H](C(C)C)n2c1nc1c(c2=O)C=C(OC)C=CO1</smiles>

3

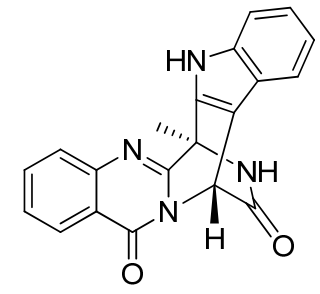

8

Figure 1. Structures of compounds 1-8 from Aspergillus sp. F452. 


\subsection{SrtA Inhibitory Activity of Compounds $\mathbf{1}-\mathbf{8}$}

Recombinant SrtA derived from S. aureus ATCC6538p was purified from Escherichia coli extracts using metal chelate-affinity chromatography [23]. The enzyme activity was determined from the fluorescence intensity upon cleavage of a peptide substrate containing the LPETG motif [24]. Throughout the separation process, the crude extract and chromatographic fractions containing fungal metabolites of strain F452 inhibited the activity of SrtA. Accordingly, the same bioassay was performed using pure compounds. The inhibitory potencies of the pure compounds against recombinant SrtA, expressed as $\mathrm{IC}_{50}$ values, are shown in Table 1 and are compared to those of the known SrtA inhibitors berberine chloride $\left(\mathrm{IC}_{50}=85.9 \mu \mathrm{M}\right)$ and para-hydroxymercuribenzoic acid $(p \mathrm{HMB})\left(\mathrm{IC}_{50}=112.5 \mu \mathrm{M}\right)$. The pure compounds 1-8 displayed weak to significant SrtA inhibition ( $\mathrm{IC}_{50}$ values of $\left.269.4-146.0 \mu \mathrm{M}\right)$. Among them, compound 1 exhibited the most potent inhibitory activity.

Table 1. Inhibitory activity of compounds 1-8 toward the activity of the SrtA enzyme and bacterial growth of S. aureus ATCC6538p.

\begin{tabular}{|c|c|c|}
\hline Compounds & SrtA IC I0 $\mu \mathrm{M}(\mu \mathrm{g} / \mathrm{mL})$ & $\operatorname{MIC} \mu \mathrm{M}(\mu \mathrm{g} / \mathrm{mL})^{1}$ \\
\hline 1 & $146.0 \pm 2.3(38.9 \pm 0.6)$ & $>480.5(>128)$ \\
\hline 2 & $269.4 \pm 3.9(92.5 \pm 1.4)$ & $>372.7(>128)$ \\
\hline 3 & $193.5 \pm 2.5(69.5 \pm 0.9)$ & $>356.1(>128)$ \\
\hline 4 & $267.9 \pm 4.1(107.8 \pm 1.5)$ & $>318.1(>128)$ \\
\hline 5 & $232.5 \pm 3.7(96.8 \pm 1.4)$ & $>307.4(>128)$ \\
\hline 6 & $216.4 \pm 2.5(93.1 \pm 1.1)$ & $>297.4(>128)$ \\
\hline 7 & $237.1 \pm 3.8(102.1 \pm 1.2)$ & $>297.4(>128)$ \\
\hline 8 & $235.1 \pm 2.6(83.8 \pm 0.9)$ & $>359.2(>128)$ \\
\hline Berberine chloride & $85.9 \pm 1.2(31.9 \pm 0.4)$ & $>332.2(>128)$ \\
\hline$p \mathrm{HMB}$ & $112.5 \pm 1.7(33.1 \pm 0.5)$ & $\mathrm{ND}^{2}$ \\
\hline Ampicillin & ND & $0.4(0.1)$ \\
\hline
\end{tabular}

${ }^{1}$ MIC means minimum inhibitory concentration. ${ }^{2}$ ND means not determined. $p$ HMB (para-hydroxymercuribenzoic acid) and berberine chloride were used as reference inhibitors of SrtA. Ampicillin was used as a standard antibacterial drug.

To determine the type of inhibition, kinetic studies were performed with compounds $\mathbf{1}$ and $\mathbf{3}$ at $\mathrm{IC}_{50}$ or twofold $\mathrm{IC}_{50}$ based on a Lineweaver and Burk plot [25] (Figure 2). Inhibitor constants were obtained by a Dixon plot. Inhibitory kinetics show that compound $\mathbf{1}$ behaved as a mixed inhibitor (Ki $=265.0 \mu \mathrm{M})$. In contrast, compound 3 behaved as an uncompetitive inhibitor $(\mathrm{Ki}=83.0 \mu \mathrm{M})$. Moreover, the binding of compounds 1 and 3 to SrtA was reversible because the enzyme activity was indeed recovered by dialysis within $2 \mathrm{~h}$, excluding the possible existence of a covalent bond between inhibitor and enzyme.

\subsection{Antibacterial Activity and Cytotoxicity of Compounds 1-8}

Because SrtA inhibitors are expected to serve as anti-infective agents and inhibit bacterial pathogenesis without affecting cell viability [8], the minimum inhibitory concentrations (MICs) of these compounds were also measured to exclude the possible effects of test compounds on S. aureus cell adhesion to the eukaryotic cell matrix protein fibronectin owing to the inhibition of cell growth. The compounds did not exhibit inhibitory activity against $S$. aureus ATCC6538p (MIC $>128 \mu \mathrm{g} / \mathrm{mL}$ ) (Table 1). In the cytotoxicity assay against A549 (lung cancer) and K562 (leukemia) cell lines, compounds 1-8 displayed weak $\left(\mathbf{2}-7\right.$ : $\left.\mathrm{IC}_{50}>13-50 \mu \mathrm{M}\right)$ to no inhibitory activity (1 and 8: $\left.\mathrm{IC}_{50}>100 \mu \mathrm{M}\right)$, comparable to etoposide $\left(\mathrm{IC}_{50}=0.5 \mu \mathrm{M}\right)$. 


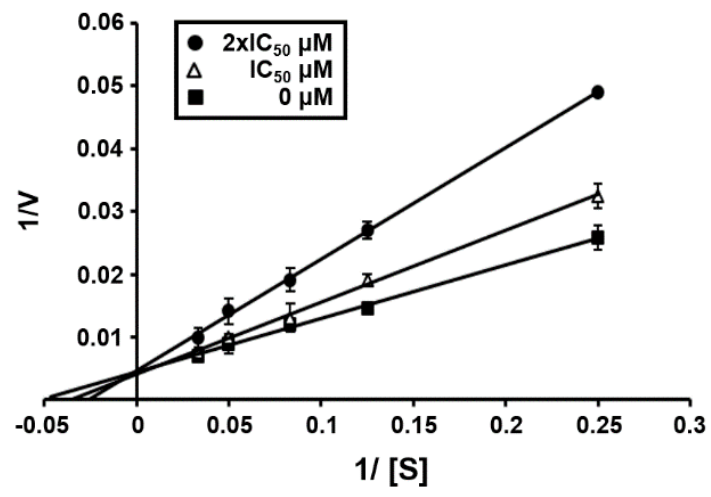

(a)

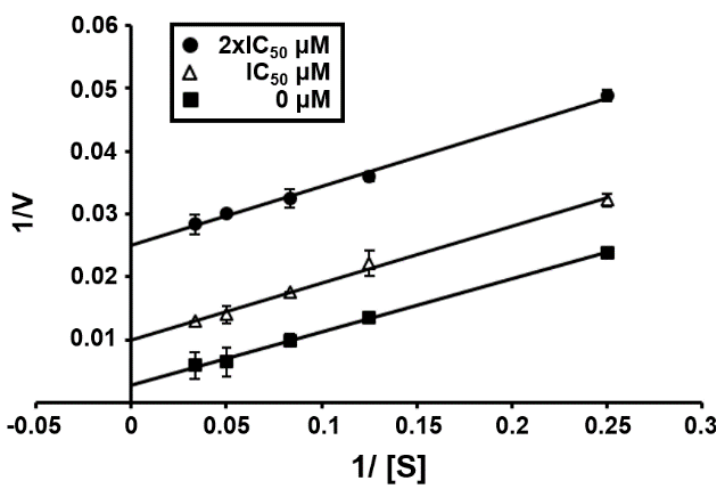

(b)

Figure 2. Lineweaver-Burk plot of SrtA inhibition by compounds $\mathbf{1}(\mathbf{a})$ and $\mathbf{3}(\mathbf{b})$. [S], substrate concentration $[\mu \mathrm{M}] ; V$, reaction velocity ( $\Delta$ absorbance unit/min). Each data point represents the mean of three experiments.

\subsection{Inhibition of SrtA-mediated S. aureus Adhesion to Fibronectin by Compound $\mathbf{1}$}

An active SrtA enzyme is required for the attachment of $S$. aureus to eukaryotic cell matrix proteins, such as fibronectin and fibrinogen, thus accelerating bacterial adhesion to host tissues and subsequent invasion [26]. The $s r t A^{-}$mutant strain cannot bind these proteins. Thus, SrtA inhibitors should inhibit SrtA activity in vivo and in turn reduce fibronectin-binding protein surface display. Initially, the SrtA-mediated fibronectin-binding capacities of S. aureus strain Newman (wild-type) and its isogenic $s r t A$ knockout mutant $\left(s r t A^{-}\right)$to fibronectin were evaluated. As shown in Figure 3a, the fibronectin-binding activity of the $s r t A$ knockout mutant was significantly reduced compared to that of the wild type. Based on SrtA inhibition intensity, compound $\mathbf{1}$ was selected. The results of the inhibition of $S$. aureus adhesion to fibronectin via fibronectin-binding protein by compound $\mathbf{1}$ are shown in Figure 3 b. As expected, treatment of strain Newman with $0-, 1-, 2-$, or 4 -fold the SrtA IC $_{50}$ of compound 1 significantly reduced bacterial adherence to fibronectin-coated surfaces. The onset and magnitude of inhibition of Newman strain adhesion to fibronectin by compound 1 with $4 \times$ the SrtA IC 50 value was comparable to the behavior of the untreated srtA knockout mutant, as shown in Figure 3a. The results of the fibronectin-binding assay suggested the potential of this compound in treating S. aureus infections through inhibition of SrtA activity.

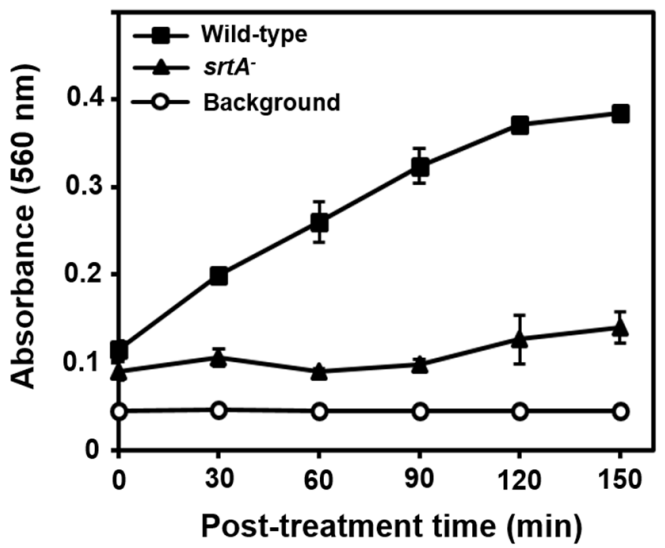

(a)

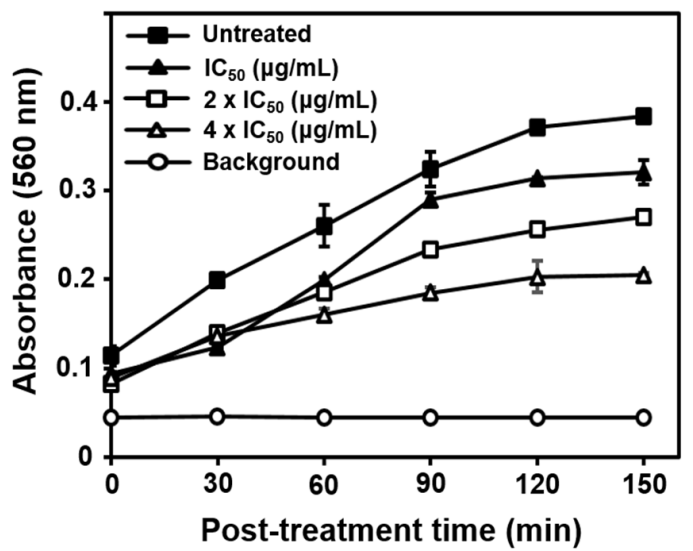

(b)

Figure 3. Adhesion of $S$. aureus strain Newman (wild-type) and the isogenic srt $A$ knockout mutant $\left(s r t A^{-}\right)$to fibronectin (a), and inhibition of Newman strain adhesion to fibronectin by compound $\mathbf{1}(\mathbf{b})$ with $0 \times, 1 \times, 2 \times$, or $4 \times$ the SrtA IC 50 value. The results are presented as the mean \pm standard deviation of three replicates. 


\section{Materials and Methods}

\subsection{General Experimental Procedures}

The UV spectra were acquired with a Hitachi U-3010 spectrophotometer (Tokyo, Japan). The NMR spectra were recorded in DMSO- $d_{6}$ solution using Bruker Avance $(400,500$, or 600$)$ instruments (Billerica, MA, USA). IR spectra were recorded on a JASCO 4200 FT-IR spectrometer (Easton, MD, USA) using a ZnSe cell. High-resolution FABMS data were acquired using a JEOL JMS 700 mass spectrometer (Tokyo, Japan) with $6 \mathrm{keV}$-energy, emission current $5.0 \mathrm{~mA}$, xenon as inert gas, and meta-nitrobenzyl alcohol (NBA) as the matrix at the Korea Basic Science Institute (Daegu, Korea). Low-resolution ESIMS data were recorded on an Agilent Technologies 6130 quadrupole mass spectrometer with an Agilent Technologies 1200 series HPLC system (Santa Clara, CA, USA). HPLC analyses were performed on a Spectrasystem p2000 equipped with a Spectrasystem RI-150 refractive index detector (Waltham, MA, USA). All of the solvents used were spectroscopic grade or distilled from glass prior to use.

\subsection{Fungal Material}

The isolation and identification of Aspergillus sp. (strain number F452) have previously been reported [15]. The fungal strain was isolated from submerged, decaying wood off the shore of Jeju Island, Korea, and identified using standard molecular biological protocols by DNA amplification and sequencing of the ITS region. The nucleotide sequence of F452 has been deposited in the GenBank database under accession number KF384188.

\subsection{Extraction and Isolation}

The isolated strain was cultivated on a YPG agar plate (5 g yeast extract, $5 \mathrm{~g}$ peptone, $10 \mathrm{~g}$ glucose, and $16 \mathrm{~g}$ agar in $1 \mathrm{~L}$ artificial seawater) for 4 days. The agar plugs $(1 \mathrm{~cm} \times 1 \mathrm{~cm}, 5$ pieces each) were inoculated into $100 \mathrm{~mL}$ YPG media in a $250 \mathrm{~mL}$ Erlenmeyer flask for 5 days, then separately transferred to $2.8 \mathrm{~L}$ glass Fernbach flasks with rice media (200 g rice, $2 \mathrm{~g}$ peptone, and $2 \mathrm{~g}$ yeast extract with 200 $\mathrm{mL}$ artificial seawater in each flask, boiled in an autoclave for $20 \mathrm{~min}$ at $120^{\circ} \mathrm{C}$; 50 flasks in total).

Fermentation in rice media was conducted under static conditions for 6 weeks followed by extraction of each flask with $\mathrm{MeOH}(1 \mathrm{~L} \times 3)$ and $\mathrm{CH}_{2} \mathrm{Cl}_{2}(1 \mathrm{~L} \times 3)$. The solvent was combined and evaporated to obtain an organic extract. The combined extracts $(247.33 \mathrm{~g}$ ) were successively partitioned between $n$ - $\mathrm{BuOH}(177.12 \mathrm{~g})$ and $\mathrm{H}_{2} \mathrm{O}(70.05 \mathrm{~g})$; the former fraction was repartitioned using $\mathrm{H}_{2} \mathrm{O}-\mathrm{MeOH}$ (15:85) (83.31 g) and $n$-hexane $\left(93.18 \mathrm{~g}\right.$ ). The $\mathrm{H}_{2} \mathrm{O}-\mathrm{MeOH}$ fraction was separated by $\mathrm{C}_{18}$ reversed-phase vacuum flash chromatography using a sequential mixture of $\mathrm{MeOH}$ and $\mathrm{H}_{2} \mathrm{O}$ as eluents (five fractions in the gradient, $\mathrm{H}_{2} \mathrm{O}-\mathrm{MeOH}$, from 60:40 to 0:100), acetone, and finally EtOAc.

Based on the results of ${ }^{1} \mathrm{H}$ NMR analyses and bioactivity tests, the $30: 70 \mathrm{H}_{2} \mathrm{O}-\mathrm{MeOH}$ fraction (9.20 g) was separated by semi-preparative reversed-phase HPLC (YMC-ODS-A column, $10 \times 250 \mathrm{~mm}$; $\left.\mathrm{H}_{2} \mathrm{O}-\mathrm{MeOH}, 50: 50 ; 1.7 \mathrm{~mL} / \mathrm{min}\right)$ and yielded compounds $1\left(t_{\mathrm{R}}=46.1 \mathrm{~min}\right), 2\left(t_{\mathrm{R}}=22.2 \mathrm{~min}\right), 3\left(t_{\mathrm{R}}=\right.$ $13.5 \mathrm{~min}), 4\left(t_{\mathrm{R}}=37.2 \mathrm{~min}\right), 5\left(t_{\mathrm{R}}=40.5 \mathrm{~min}\right), 6\left(t_{\mathrm{R}}=66.9 \mathrm{~min}\right), 7\left(t_{\mathrm{R}}=74.1 \mathrm{~min}\right)$, and $8\left(t_{\mathrm{R}}=15.4 \mathrm{~min}\right)$. Compounds 1, 4, and 5 were further purified by analytical HPLC (YMC-ODS-A column, $4.6 \times 250 \mathrm{~mm}$; $\mathrm{H}_{2} \mathrm{O}-\mathrm{MeCN}, 65: 35 ; 0.7 \mathrm{~mL} / \mathrm{min} ; t_{\mathrm{R}}=18.2,11.9$, and $14.5 \mathrm{~min}$, respectively). The purified metabolites were isolated at the following yields: 5.5, 3.4, 4.4, 2.9, 5.1, 9.3, 1.9, and 7.9 $\mathrm{mg}$ for 1-8, respectively.

\subsection{SrtA Inhibition Assay}

The srtA gene from $S$. aureus ATCC6538p was expressed and recombinant SrtA was purified as previously described [23]. The SrtA inhibition test was carried out by analyzing the increased fluorescence intensity resulting from the cleavage of synthetic peptide substrate dabcyl-LPETG-edans (AnaSpec, Inc., Fremont, CA, USA) [9,24] with slight modification. The reaction was carried out with $100 \mu \mathrm{L}$ buffer (50 mM Tris- $\mathrm{HCl}, 5 \mathrm{mM} \mathrm{CaCl}_{2}$, and $\left.150 \mathrm{mM} \mathrm{NaCl}, \mathrm{pH} 7.5\right), 7.5 \mu \mathrm{M}$ synthetic peptide, $7.5 \mu \mathrm{M}$ purified SrtA, and test samples at various concentrations. Each sample was dissolved in dimethyl sulfoxide (DMSO) and diluted with reaction buffer to obtain a final concentration of $1 \%$ DMSO, 
which did not influence enzyme activity. The SrtA inhibition assay was conducted at $37^{\circ} \mathrm{C}$ for $1 \mathrm{~h}$, and inhibition was quantified fluorometrically using a microplate reader (FLx800, BioTek Instruments, Winooski, VT, USA) at excitation and emission wavelengths of 350 and $495 \mathrm{~nm}$, respectively. $p \mathrm{HMB}$ and berberine chloride were used as reference inhibitors of SrtA.

\subsection{Enzyme Kinetics}

All sortase (SrtA) assays were performed at $37^{\circ} \mathrm{C}$ in SrtA enzyme buffer as described above. The inhibitors 1 and 3 were dissolved in DMSO and immediately diluted to the desired working concentration with the same SrtA buffer. The enzymatic inhibition measurements were carried out at different substrate concentrations in the presence and absence of a given concentration of inhibitor, and their kinetics were evaluated by the Lineweaver and Burk plot method [25]. For the dialysis kinetic studies, a solution of enzyme $(0.96 \mathrm{~mL}, 75 \mu \mathrm{M})$ and fixed inhibitor concentration $(0.04 \mathrm{~mL})$ was prepared and dialyzed against $100 \mathrm{~mL}$ buffer at $37^{\circ} \mathrm{C}$ for $2 \mathrm{~h}$ using regenerated cellulose dialysis membranes SPECTRAPOR ${ }^{\circledR}$ (Rancho Dominguez, CA, USA). Aliquots of $100 \mu \mathrm{L}$ of the enzyme-inhibitor mixture were taken in time intervals of $0,30,60,90$, and $120 \mathrm{~min}$ and added to $0.020 \mathrm{~mL}$ of substrate $(7.5 \mu \mathrm{M})$, and after an hour of incubation the enzyme activity was measured. A control solution prepared with enzyme and buffer (SrtA buffer, $100 \mu \mathrm{L} ;$ SrtA, $7.5 \mu \mathrm{M}$ ) was treated similarly.

\subsection{Antibacterial Activity Assay}

The MICs of test compounds were determined as previously described [27]. S. aureus ATCC6538p $(5 \mathrm{~mL})$ was cultured in tryptic soy broth to saturation at $37^{\circ} \mathrm{C}$ and diluted to an $\mathrm{OD}_{600}$ of 0.01 . The culture was incubated for an additional $2 \mathrm{~h}$ and diluted to an $\mathrm{OD}_{600}$ of 0.005 . In each well of a 96-well plate, $180 \mu \mathrm{L}$ of cells was mixed with $20 \mu \mathrm{L}$ of a concentrated test compound solution in $10 \%$ DMSO (final concentration, $1 \%$ DMSO). Culture plates were incubated overnight at $37^{\circ} \mathrm{C}$, and the $\mathrm{OD}_{600}$ was measured using a Multiskan Spectrum spectrophotometer (Thermo Labsystems Inc., Beverly, MA, USA). MIC values were defined as the lowest concentration of the test compounds inhibiting cell growth. Ampicillin was used as a positive control.

\subsection{Cytotoxicity Assay}

The effect of compounds (1-8) on cell proliferation was measured by the sulforhodamine B (SRB) cellular protein-staining method [28]. In brief, A549 (lung cancer) and K562 (leukemia) cells ( $1 \times$ $10^{4}$ cells in $190 \mu \mathrm{L}$ of complete DMEM) were seeded in 96-well plates with various concentrations of compounds (1-8) and incubated at $37^{\circ} \mathrm{C}$ in a humidified atmosphere with $5 \% \mathrm{CO}_{2}$. After $72 \mathrm{~h}$ of compound (1-8) treatment, the cells were fixed with $10 \%$ TCA solution for $1 \mathrm{~h}$, and cellular proteins were stained with a solution of $0.4 \%$ SRB in $1 \%$ acetic acid. The stained cells were dissolved in $10 \mathrm{mM}$ Tris buffer ( $\mathrm{pH}$ 10.0). The effect of compounds (1-8) on cell viability was calculated as a percentage relative to a solvent-treated control, and the $\mathrm{IC}_{50}$ values were calculated using a nonlinear regression analysis (percent survival versus concentration). Etoposide was used as a positive control.

\subsection{Fibronectin-Binding Assay}

S. aureus strains used were Newman (wild-type) and the isogenic $\operatorname{srt} A$ knockout mutant (srt $\left.A^{-}\right)$[9]. These strains were cultured in tryptic soy broth at $37^{\circ} \mathrm{C}$ at $200 \mathrm{rpm}$ up to mid-log phase $\left(\mathrm{OD}_{600}\right.$ $=0.5$ ). The fibronectin-binding assay was performed as described previously $[24,29]$. Cells were treated with test compounds at their indicated concentrations. Every $30 \mathrm{~min}$ for $2.5 \mathrm{~h}$, a $0.65 \mathrm{~mL}$ cell suspension was centrifuged at $10,000 \times g$ for $10 \mathrm{~min}$, and the supernatant was eliminated. Following incubation overnight at $-20^{\circ} \mathrm{C}$, pellets were resuspended in $0.65 \mathrm{~mL}$ phosphate-buffered saline (PBS) and distributed as a $100 \mu \mathrm{L}$ scale in fibronectin-coated flat-bottomed 96-well plates (Corning Life Sciences, Tewksbury, MA, USA). The cell suspension was removed and washed with PBS following incubation at $37^{\circ} \mathrm{C}$ for $2 \mathrm{~h}$. Bound cells were fixed via incubation with $2 \%(v / v)$ glutaraldehyde for 30 min. After a second wash with PBS, cells were stained for 15 min with $100 \mu \mathrm{L}$ crystal violet dye (12.5 
g/L). Each well was washed with PBS and covered with aluminum foil. Plates were dried overnight and absorbance was measured at $560 \mathrm{~nm}$ using a microplate reader.

\section{Conclusions}

Seven alkaloidal compounds (2-8) and one polyketide (1) were isolated from a semisolid rice culture of the marine-derived fungus Aspergillus sp. F452. The structures of these compounds were obtained through a combination of spectroscopic analyses, and their data were in good agreement with previous reports. Bioactivity studies have revealed that compound $\mathbf{1}$ from a marine-derived fungus Aspergillus sp., separated from the mussel Mytilus edulis, shows significant neurotrophic effects on PC-12 cells [17]. Compound 3 from the deep sea-derived A. versicolor SCSIO 05,879 exhibits antifungal activity against the phytopathogenic fungus Colletotrichum acutatum (minimum inhibitory concentration (MIC) of $1.6 \mu \mathrm{g} / \mathrm{mL}$ ) [19]. Compounds 4-7 from a marine-derived fungus Aspergillus sp. F452 exhibit weak inhibition against $\mathrm{Na}^{+} / \mathrm{K}^{+}$-ATPase $\left(\mathrm{IC}_{50}\right.$ values of 20-78 $\left.\mu \mathrm{M}\right)$ [20]. Compound 6 also displays weak inhibition against Bacillus subtilis, and compound 7 from A. fumigatus, an endophytic fungus, shows weak cytotoxic activity against the human prostate cancer cell line PC3 [21]. In our measurement of SrtA enzyme activity, compounds 1-8 displayed moderate to significant SrtA inhibition, comparable to berberine chloride and $p \mathrm{HMB}$, against $S$. aureus-derived SrtA, a transpeptidase responsible for anchoring surface proteins to the peptidoglycan cell wall in Gram-positive bacteria. Further bioassays of compound 1 indicated that the underlying mechanism of action was associated with the inhibition of adhesion of $S$. aureus to fibronectin via fibronectin-binding protein. Our results demonstrate the potential of these metabolites for the development of new agents to treat Gram-positive bacterial infections by inhibiting SrtA activity.

Author Contributions: S.C.P. and J.-Y.H. carried out the isolation and structural elucidation; B.C. performed the fibronectin-binding assays; J.L. and E.C. contributed to the SrtA inhibition and antibacterial activity assays; D.-C.O. reviewed and evaluated all data; J.S. and K.-B.O. supervised the research work and prepared the paper. All authors have read and agreed to the published version of the manuscript.

Funding: This research was supported by the Basic Science Research Program through the National Research Foundation (NRF, grant No. 2018R1D1A1B07043375) of Korea funded by the Ministry of Education, Science and Technology and the NRF (grant No. 2018R1A4A1021703) of Korea funded by the Ministry of Science, ICT and Future Planning. This work was also supported by the BK21 Plus Program of the Department of Agricultural Biotechnology, Seoul National University, Seoul, Korea.

Acknowledgments: We thank the Basic Science Research Institute in Daegu, Korea, for providing the mass data and the National Center for Inter-University Research Facilities (NCIRF), Seoul National University, for providing the NMR data.

Conflicts of Interest: The authors declare no conflict of interest.

\section{References}

1. Gould, I.M. Antibiotic resistance: The perfect storm. Int. J. Antimicrob Agents 2009, 34, S2-S5. [CrossRef]

2. Maresso, A.W.; Schneewind, O. Sortase as a target of anti-infective therapy. Pharm. Rev. 2008, 60, $128-141$. [CrossRef] [PubMed]

3. Cascioferro, S.; Totsika, M.; Schillaci, D. Sortase A: An ideal target for anti-virulence drug development. Microb. Pathog. 2014, 77, 105-112. [CrossRef] [PubMed]

4. Rasko, D.A.; Sperandio, V. Anti-virulence strategies to combat bacteria-mediated disease. Nat. Rev. Drug. Discov. 2010, 9, 117-128. [CrossRef] [PubMed]

5. Hendrickx, A.P.; Budzik, J.M.; Oh, S.Y.; Schneewind, O. Architects at the bacterial surface-sortases and the assembly of pili with isopeptide bonds. Nat. Rev. Microbiol. 2011, 9, 166-176. [CrossRef]

6. Mazmanian, S.K.; Skaar, E.P.; Gaspar, A.H.; Humayun, M.; Gornicki, P.; Jelenska, J.; Joachmiak, A.; Missiakas, D.M.; Schneewind, O. Passage of heme-iron across the envelope of Staphylococcus aureus. Science 2003, 299, 906-909. [CrossRef]

7. Clancy, K.W.; Melvin, J.A.; McCafferty, D.G. Sortase transpeptidases: Insights into mechanism, substrate specificity and inhibition. Biopolymers 2010, 94, 385-396. [CrossRef] 
8. Mazmanian, S.K.; Liu, G.; Jensen, E.R.; Lenoy, E.; Schneewind, O. Staphylococcus aureus sortase mutants defective in the display of surface proteins and in the pathogenesis of animal infections. Proc. Natl. Acad. Sci. USA 2000, 97, 5510-5515. [CrossRef]

9. Mazmanian, S.K.; Ton-That, H.; Su, K.; Schneewind, O. An iron-regulated sortase anchors a class of surface protein during Staphylococcus aureus pathogenesis. Proc. Natl. Acad. Sci. USA 2002, 99, 2293-2298. [CrossRef]

10. Weiss, W.J.; Lenoy, E.; Murphy, T.; Tardio, L.; Burgio, P.; Projan, S.J.; Schneewind, O.; Alksne, L. Effect of srtA and srtB gene expression on the virulence of Staphylococcus aureus in animal models of infection. $J$. Antimicrob. Chemother 2004, 53, 480-486. [CrossRef]

11. Rateb, M.E.; Ebel, R. Secondary metabolites of fungi from marine habitats. Nat. Prod. Rep. 2011, 28, $290-344$. [CrossRef] [PubMed]

12. Jin, L.; Quan, C.; Hou, X.; Fan, S. Potential pharmacological resources: Natural bioactive compounds from marine-derived fungi. Mar. Drugs 2016, 14, 76. [CrossRef]

13. Youssef, F.S.; Ashour, M.L.; Singab, A.N.B.; Wink, M. A comprehensive review of bioactive peptides from marine fungi and their biological significance. Mar. Drugs 2019, 17, 559. [CrossRef] [PubMed]

14. Julianti, E.; Lee, J.-H.; Liao, L.; Park, W.; Park, S.; Oh, D.-C.; Oh, K.-B.; Shin, J. New polyaromatic metabolites from a marine-derived fungus Penicillium sp. Org. Lett. 2013, 15, 1286-1289. [CrossRef] [PubMed]

15. Liao, L.; Bae, S.Y.; Won, T.H.; You, M.; Kim, S.-H.; Oh, D.-C.; Lee, S.K.; Oh, K.-B.; Shin, J. Asperphenins A and B, lipopeptidyl benzophenones from a marine-derived Aspergillus sp. fungus. Org. Lett. 2017, 19, 2066-2069. [CrossRef] [PubMed]

16. Hwang, J.-Y.; Lee, J.-H.; Park, S.C.; Lee, J.; Oh, D.-C.; Oh, K.-B.; Shin, J. New peptides from the marine-derived fungi Aspergillus allahabadii and Aspergillus ochraceopetaliformis. Mar. Drugs 2019, 17, 488. [CrossRef]

17. Tsukamoto, S.; Miura, S.; Yamashita, Y.; Ohta, T. Aspermytin A: A new neurotrophic polyketide isolated from a marine-derived fungus of the genus Aspergillus. Bioorg. Med. Chem. Lett. 2004, 14, 417-420. [CrossRef]

18. Pan, C.; Shi, Y.; Chen, X.; Chen, C.-T.A.; Tao, X.; Wu, B. New compounds from a hydrothermal vent crab-associated fungus Aspergillus versicolor XZ-4. Org. Biomol. Chem. 2017, 15, 1155-1163. [CrossRef]

19. Wang, J.; He, W.; Huang, X.; Tian, X.; Liao, S.; Yang, B.; Wang, F.; Zhou, X.; Liu, Y. Antifungal new oxepine-containing alkaloids and xanthones from the deep-sea-derived fungus Aspergillus versicolor SCSIO 05879. J. Agric. Food Chem. 2016, 64, 2910-2916. [CrossRef]

20. Liao, L.; You, M.; Chung, B.K.; Oh, D.-C.; Oh, K.-B.; Shin, J. Alkaloidal metabolites from a marine-derived Aspergillus sp. fungus. J. Nat. Prod. 2015, 78, 349-354. [CrossRef]

21. Xie, F.; Li, X.-B.; Zhou, J.-C.; Xu, Q.-Q.; Wang, X.-N.; Yuan, H.-Q.; Lou, H.-X. Secondary metabolites from Aspergillus fumigatus, an endophytic fungus from the liverwort Heteroscyphus tener (Steph) Schiffn. Chem. Biodivers. 2015, 12, 1313-1321. [CrossRef] [PubMed]

22. Heredia, M.L.; de la Cuesta, E.; Avendano, C. Acid-promoted reactions in 1-hydroxy, 1-dimethylaminomethyl and 1-methylene-4-arylmethyl-2,4-dihydro-1H-pyrazino[2,1-b]-quinazoline-3,6-diones. Tetrahedron 2002, 58, 6163-6170. [CrossRef]

23. Oh, K.-B.; Kim, S.-H.; Lee, J.; Cho, W.-J.; Lee, T.; Kim, S. Discovery of diarylacrylonitriles as a novel series of small molecule sortase A inhibitors. J. Med. Chem. 2004, 47, 2418-2421. [CrossRef] [PubMed]

24. Oh, K.-B.; Oh, M.-N.; Kim, J.-G.; Shin, D.-S.; Shin, J. Inhibition of sortase-mediated Staphylococcus aureus adhesion to fibronectin via fibronectin-binding protein by sortase inhibitors. Appl. Microbiol. Biotechnol. 2006, 70, 102-106. [CrossRef]

25. Lineweaver, H.; Burk, D. The determination of enzyme dissociation constants. J. Am. Chem. Soc. 1934, 56, 658-666. [CrossRef]

26. Alksne, L.E.; Projan, S.J. Bacterial virulence as a target for antimicrobial chemotherapy. Curr. Opin. Biotechnol. 2000, 11, 625-636. [CrossRef]

27. Frankel, B.A.; Bentley, M.; Kruger, R.G.; McCafferty, D.G. Vinyl sulfones: Inhibitors of srtA, a transpeptidase required for cell wall protein anchoring and virulence in Staphylococcus aureus. J. Am. Chem. Soc. 2004, 126, 3404-3405. [CrossRef] 
28. Kim, T.S.; Shin, Y.-H.; Lee, H.-M.; Kim, J.K.; Choe, J.H.; Jang, J.-C.; Um, S.; Jin, H.S.; Komatsu, M.; Cha, G.-H.; et al. Ohmyungsamycins promote antimicrobial responses through autophagy activation via AMP-activated protein kinase pathway. Sci. Rep. 2017, 7, 3431. [CrossRef]

29. Elgalai, I.; Foster, H.A. Comparison of adhesion of wound isolates of Staphylococcus aureus to immobilized proteins. J. Appl. Micrbiol. 2003, 94, 413-420. [CrossRef]

(C) 2020 by the authors. Licensee MDPI, Basel, Switzerland. This article is an open access article distributed under the terms and conditions of the Creative Commons Attribution (CC BY) license (http://creativecommons.org/licenses/by/4.0/). 